\title{
Comprehensive psycholexical classification of Polish person-descriptive terms
}

\author{
Oleg Gorbaniuk ${ }^{1,2 \cdot A, B, C, D, E, F, G}$, Anna Korczak ${ }^{1 \cdot C, D, F}$, Nasturcja Toruj $^{1 \cdot B, D}$, Anna Czarnejko ${ }^{1 \cdot B, D}$, \\ Krystian Macheta ${ }^{1,3 \cdot D, F}$, Magdalena Jałoszewska ${ }^{1 \cdot B, D}$, Małgorzata Charęzińska-Nowocień ${ }^{1 \cdot B, D}$, \\ Rafat Karpiński ${ }^{1 \cdot B, D}$, Łukasz Garwoliński ${ }^{1 \cdot B, D}$, Tomasz Misiuro ${ }^{2 \cdot B, D, G}$, Milena Zygnerska ${ }^{1 \cdot B, D}$, \\ Iwona Bojan ${ }^{1 \cdot D}$, Karolina Rykowska ${ }^{1 \cdot D}$, Paula Wawrzaszek ${ }^{1 \cdot D}$, Juliusz Jeliński ${ }^{1 \cdot D}$, \\ Marta Hawryluk $k^{1 \cdot D}$
}

1: Institute of Psychology, The John Paul II Catholic University of Lublin, Poland

2: Institute of Psychology, University of Zielona Góra, Poland

3: Department of Psychology, Pedagogical University of Cracow, Poland

\section{BACKGROUND}

Lexical research based on the assumption that all the main human characteristics are encoded in the natural language constitutes one of the alternative ways of developing a taxonomy of individual differences in psychology. The majority of studies to date, including Polish ones, have been restricted to the analysis of the adjective lexicon, which means their results are at risk of reductionism. The aim of the presented research was to develop a classification of the complete Polish lexicon of person-descriptive terms (adjectives, participles, adverbs, nouns, and verbs).

\section{PARTICIPANTS AND PROCEDURE}

We analyzed 100,000 entries found in a universal dictionary of Polish and identified 27,813 terms used to describe human characteristics. The identified person-descriptive terms were classified by a team of 13 trained judges into 16 subcategories. The judges' taxonomic decisions were tested for validity and reliability.

\section{RESULTS}

Personality (dispositional) descriptors $(5,598)$ constitute $20.1 \%$ of the Polish lexicon of person-descriptors; this in- cludes 1,641 adjectives and participles, 612 adverbs, 1,442 attribute-nouns, 1,029 type-nouns, and 916 verbs. The analysis of the semantic redundancy of terms representing different parts of speech but having the same common morpheme among dispositional descriptors revealed 1,979 morphemes with distinct meanings. Only $64 \%$ of these morphemes are represented by adjectives.

\section{CONCLUSIONS}

Adjectives constitute the largest group of personality (dispositional) descriptors but do not account for the entire Polish personality lexicon. The results of the study are a point of departure for research into the specificity of the structure of personality descriptions in the Polish language using various linguistic categories and for a comprehensive study on the entire Polish personality lexicon.

\section{KEY WORDS}

individual differences; psycholexical taxonomy; personality lexicon; Polish language

Corresponding AUthor - Oleg Gorbaniuk, Ph.D., Institute of Psychology, The John Paul II Catholic University of Lublin,

14 Racławickie Avenue, 20-950 Lublin, Poland, e-mail: oleg.gorbaniuk@gmail.com

AUthors' Contribution - A: Study design - B: Data collection - C: Statistical analysis - D: Data interpretation .

E: Manuscript preparation $\cdot F$ : Literature search $\cdot$ G: Funds collection

to Cite this ARTicle - Gorbaniuk, O., Korczak, A., Toruj, N., Czarnejko, A., Macheta, K., Jałoszewska, M., Charęzińska-

Nowocień, M., Karpiński, R., Garwoliński, Ł., Misiuro, T., Zygnerska, M., Bojan, I., Rykowska, K., Wawrzaszek, P.,

Jeliński, J., \& Hawryluk, M. (2019). Comprehensive psycholexical classification of Polish person-descriptive terms.

Current Issues in Personality Psychology, 7(2), 142-154.

RECEIVED 13.11.2018 · REVIEWED 11.01.2019 • ACCEPTED 14.01.2019 • PUBLISHED 07.02.2019 
O. Gorbaniuk, A. Korczak, N. Toruj, A. Czarnejko, K. Macheta, M. Jałoszewska, M. Charęzińska-Nowocień, R. Karpiński, Ł. Garwoliński, T. Misiuro, M. Zygnerska, I. Bojan, K. Rykowska, P. Wawrzaszek, J. Jeliński, M. Hawryluk

\section{BACKGROUND}

The taxonomy of the abundance of individual differences between people is one of the important areas of interest in psychology. One of the approaches, which has made it possible to reach relatively high taxonomic agreement among researchers, is the lexical approach. The use of a similar methodology in research devoted to various natural languages has contributed to a considerable degree of consensus about the structure of characteristics universal across cultures, meeting most of the requirements for structural models (Saucier \& Srivastava, 2015). The point of departure in the lexical approach is the lexical assumption, originally proposed by Galton (1884) and reformulated nearly 100 years later by Goldberg (1981). According to him, the most important individual differences have been observed by people and named in the course of evolution in order for individuals to be able to communicate them to others. If these observations were regarded as useful by other users of a given language and if they are still valid, the terms referring to the observed differences have survived until the present day and function as part of the lexicon of that language. The more important an individual difference is, the more terms have been created to refer to this difference, taking the form of synonyms and antonyms, for instance. Therefore, in order to identify the individual differences that are the most important to the users of a given language, one should analyze the structure of the language used to describe them. Currently, studies devoted to the structure of personality traits constitute the largest number of studies on the lexicon of individual differences. Their outcomes include the Big Five (Goldberg, 1990; Peabody \& De Raad, 2002), the Big Six (Ashton et al., 2004), or the Big Seven (Almagor, Tellegen, \& Waller, 1995). The Big Five and the Big Six became the basis for developing, respectively, the five-factor model (OCEAN/FFM; McCrae \& Costa, $1985,1987)$ and the six-factor model (HEXACO; Lee \& Ashton, 2004, 2006) of personality, which have been measured by means of numerous questionnaires often used to measure personality traits (e.g., NEO-FFI: Costa, McCrae, \& Dye, 1991; BFI: John \& Srivastava, 1999).

A personality study can be called lexical and its results can be compared with the results of studies devoted to other natural languages if it is based on a representative sample of the personality lexicon of that language and if the factor structure of this list of personality terms has been established on the basis of a representative sample of personality descriptions generated by the users of that language (De Raad, 1998; De Raad \& Ostendorf, 1996; Saucier, 1997). Due to the time-consuming nature of lexical research, the structure of the personality lexicon has been explored to date in about 30 natural languages out of the several thousand that exist in the world, which still limits the possibilities of formulating conclusions about personality traits universal across different cultures. Moreover, the method applied in research on the languages investigated so far is not free from limitations; the most important one among them is the fact that research on the lexicon of individual differences was restricted to the adjective lexicon. This involves the risk of reductionism: a personality trait could be exclusively a characteristic that it is possible to describe by means of an adjective, and what cannot be described by means of adjectives would not be considered a personality descriptor, which goes against the lexical assumption. Both in the case of the languages examined so far and in the case of those not examined yet, there is a need to verify whether the non-adjectival personality lexicon describes the same personality traits, or whether some of them have been ignored so far due to the error of reductionism.

Psychologists tend to give personality a rather wide definition while measuring it with instruments that capture only a part of this grand, inclusive range (Saucier, 2009a). Also in psycholexical studies, we can distinguish two approach based on a narrow vs. a wide operational definition of personality, which is expressed in how one selects variables when studying the phenomena of personality (Saucier, 2009b). According to the restrictive/narrow approach, personality dispositions are indicated only by terms that primarily describe an enduring pattern of typical behavioral tendency in action, thought, and emotions (Ashton \& Lee, 2005). This approach excludes terms which are considered as highly evaluative (e.g., dumb, sleazy, backward) or referring to states (e.g., anxious, pensive, frustrated) or describing effects an individual has on others (e.g., frustrating, astonishing, boring) - either at the stage of compiling the personality lexicon or at the stage of research aimed at identifying the factor structure of personality descriptions. According to the non-restrictive/ inclusive approach, most above-mentioned terms are included in the study of structure of personality lexicon (e.g., Almagor et al., 1995; Benet-Martinez \& Waller, 1997; Tellegen \& Waller, 1987). Inclusive variable selection enables the researcher to find additional sources of variance of personality descriptions (Saucier, 2009a).

Comprehensive and unrestrictive research, based on the complete lexicon of individual differences potentially useful in personality description, has so far been conducted only in the Dutch language (De Raad \& Barelds, 2008). Studies of specific categories of individual differences such as pure evaluations, social effects or worldviews have been conducted only in a few languages (De Raad, Van Oudenhoven, \& Hofstede, 2005; Krauss, 2006; Mlačić, 2016; Saucier, 2000, 2010). 


\section{RESEARCH OBJECTIVE}

Polish is a natural language belonging to the West Slavic group of languages and to the Indo-European family of languages. It is estimated that Polish is the mother tongue for approximately 40 million people (Simons \& Fennig, 2018). Although the Polish language has been twice subjected to independent psycholexical analyses (Szarota, 1995; Gorbaniuk, Czarnecka, \& Chmurzyńska, 2011) and is included in nearly all comparisons aimed at identifying culturally universal personality traits (e.g., Ashton et al., 2004; De Raad et al., 2010; De Raad, Perugini, Hrebícková, \& Szarota, 1998; Peabody \& De Raad, 2002), both lexical studies were limited to adjectives only. The aim of the presented research was to systematize and classify the complete domain of Polish person-descriptive terms based on homogeneous and up-to-date lexical data in order to provide the basis for future quantitative studies on the factor structure of individual differences in the Polish language. This main objective can be made more specific in the form of the following research questions: Q1: How many person-descriptive terms are there in Polish? What proportion of Polish person-descriptive terms does each word class (nouns, adjectives, adverbs, verbs, and participles) account for?

Q2: What is the proportion of dispositional descriptors out of all categories of person-descriptive terms in Polish?

Q3: Does the psycholexical structure of Polish person-descriptive terms differ across word classes?

Q4: Do adjectives morphemically and semantically account for the entire Polish personality lexicon?

Q5: Do Polish dispositional adjectives account for all the markers of the cross-language Big Factors?

Due to the exploratory character of the study, we did not formulate research hypotheses.

\section{METHOD}

\section{THE SELECTION OF PERSON-DESCRIPTIVE TERMS}

As the basis for the selection of words describing individual differences in Polish, we chose the electronic version of The Universal Dictionary of the Polish Language (Uniwersalny Stownik fezyka Polskiego; Dubisz, 2008), containing 100,000 entries. According to the independent opinions of six top Polish linguists whom we consulted about the choice, this dictionary was the most complete and up-to-date source of the Polish lexicon at the beginning of the selection process (in 2014). The selection of person-descriptive terms was carried out by eight graduate (fourth- and fifth-year) and doctoral (third- and fourth-year) psychology students writing their MA theses and doctoral dissertations in the field of psycholexical research. Before commencing the selection, all the judges went through three-month theoretical and practical training, concluded by writing a chapter of their diploma thesis devoted to a review of the previous selections and classifications of person-descriptive terms. During practical training, the judges twice performed trial selection based on 200 words; the results of the trial selection were discussed in the light of the adopted selection criteria.

Person-descriptive terms are defined in this study as all of the attributes differentiating people. When deciding on whether a given word was a person-descriptive term, the judges applied the selection criteria and test sentences (see Table 1) proposed by Angleitner, Ostendorf and John (1990). The following categories of words were used as exclusion criteria: (1) words that do not differentiate people from one another and that describe the characteristics of all people; (2) words that refer to geographical origin, nationality, citizenship, and religious or professional affiliation; (3) terms that are rarely understood as describing human characteristics; (4) words describing colors or their shades; (5) numerals.

The selection of person-descriptive terms was performed separately for each of the four groups of lexical items: (1) adjectives, participles, adverbs; (2) attribute-nouns; (3) type-nouns; (4) verbs. This was done by a different pair of judges, each of them working independently. In the case of doubts regarding whether a given word met the criteria for a person-descriptive term, the judge put it on the list because in subsequent stages the list was rated by a larger number of judges. In their decisions, the judges first relied on their own understanding of the word and then on its meaning as defined in the dictionary; they copied the definition that suggested the usefulness of the word in describing human characteristics into the database and supplemented the definition with their own when they decided that the dictionary definition was insufficient in the light of the word's practical usage. This made it possible to minimize both the influence of particular judges' linguistic competence on selection results and the effect of additional meanings of the analyzed word, significant in describing individual differences, not being included in the dictionary.

We tentatively classified all the words selected by at least one judge as person-descriptive terms, so as to minimize the likelihood of excluding any words during selection that can be used to describe human characteristics. The selection of person-descriptive terms representing different word classes minimized the likelihood of missing a morpheme based on which it is possible to form useful descriptors of individual differences. Differences in the selection of words were then analyzed by one $\mathrm{PhD}$ holder in 
O. Gorbaniuk, A. Korczak, N. Toruj, A. Czarnejko, K. Macheta, M. Jałoszewska, M. Charęzińska-Nowocień, R. Karpiński, Ł. Garwoliński, T. Misiuro, M. Zygnerska, I. Bojan, K. Rykowska, P. Wawrzaszek, J. Jeliński, M. Hawryluk

Table 1

Test sentences used in the selection of person-descriptive terms

\begin{tabular}{|c|c|c|}
\hline Word class & Heuristic criterion sentence & Example \\
\hline \multirow[t]{2}{*}{$\begin{array}{l}\text { Adjectives } \\
\text { and } \\
\text { participles }\end{array}$} & $\begin{array}{l}\text { Jan jest [przymiotnik]. } \\
\text { John is [adjective]. }\end{array}$ & $\begin{array}{l}\text { tagodny [gentle or mild], sprawiedliwy } \\
\text { [fair, just], przystojny [handsome], } \\
\text { pobożny [pious] }\end{array}$ \\
\hline & $\begin{array}{l}\text { Jak bardzo [przymiotnik] jestem? } \\
\text { How [adjective] am I? }\end{array}$ & $\begin{array}{l}\text { wysoki [tall], uczuciowy [emotional, } \\
\text { sentimental], biedny [poor], pobudzony } \\
\text { [excited] }\end{array}$ \\
\hline Adverbs & $\begin{array}{l}\text { Jak (bardzo) [przysłówek] Jan się zachowuje? } \\
\text { How [adverb] did John behave? }\end{array}$ & uczciwie [honestly], spokojnie [calmly] \\
\hline \multirow[t]{3}{*}{$\begin{array}{l}\text { Attribute } \\
\text { nouns }\end{array}$} & $\begin{array}{l}\text { [Rzeczownik] Jana jest zadziwiające. } \\
\text { John's [noun] is remarkable. }\end{array}$ & $\begin{array}{l}\text { zrównoważenie [balanced], skupienie } \\
\text { [focusing], prawdomówność [truthfulness }\end{array}$ \\
\hline & $\begin{array}{l}\text { Czy on/ona ma/posiada [rzeczownik]? } \\
\text { Does he/she have or possess [noun]? }\end{array}$ & $\begin{array}{l}\text { cierpliwość [patience], logikę [logic], } \\
\text { wynalazczość [inventiveness] }\end{array}$ \\
\hline & $\begin{array}{l}\text { W jakim stopniu cechuje go [rzeczownik]? } \\
\text { To what extent [noun] characterizes him? }\end{array}$ & $\begin{array}{l}\text { kreatywność [creativity], ktamliwość } \\
\text { [falseness], stowność [reliability], } \\
\text { roztargnienie [distraction] }\end{array}$ \\
\hline \multirow[t]{2}{*}{ Type-nouns } & $\begin{array}{l}\text { Czy Jan jest [rzeczownik]? } \\
\text { Is John a [noun]? }\end{array}$ & $\begin{array}{l}\text { konserwatysta [conservative], ojcem } \\
{[\text { father], cholerykiem }[\text { choleric] }}\end{array}$ \\
\hline & $\begin{array}{l}\text { Czy można go/ja nazwać [rzeczownik]? } \\
\text { Can you call him/her a [noun]? }\end{array}$ & $\begin{array}{l}\text { tchórzem [coward], zdrajca [traitor], } \\
\text { zbawicielem [savior] }\end{array}$ \\
\hline \multirow[t]{4}{*}{ Verbs } & $\begin{array}{l}\text { Jan jest osoba, która często/rzadko/nigdy } \\
\text { [czasownik]. } \\
\text { John is a person who often/rarely/never } \\
\text { [verb]. }\end{array}$ & $\begin{array}{l}\text { płacze [cries], spóźnia się [is late], } \\
\text { denerwuje [annoys], medytuje [meditates] }\end{array}$ \\
\hline & $\begin{array}{l}\text { Jan jest osoba, która umie/potrafi lepiej/ } \\
\text { gorzej od Pawta [czasownik]. } \\
\text { John is a person who can [verb] better/ } \\
\text { worse than Paul. }\end{array}$ & $\begin{array}{l}\text { kłamać [lie], tańczyć [dance], pracować } \\
\text { [work] }\end{array}$ \\
\hline & $\begin{array}{l}\text { Jan lubi [czasownik]. } \\
\text { John likes [verb]. }\end{array}$ & $\begin{array}{l}\text { ponarzekać [complain], napsioczyć } \\
\text { [grumble] }\end{array}$ \\
\hline & $\begin{array}{l}\text { Jan często/nigdy/rzadko [czasownik] innych. } \\
\text { John often/rarely/never [verbs] other people. }\end{array}$ & frustruje [frustrates], godzi [reconciles] \\
\hline
\end{tabular}

psychology and two doctoral students in psychology. The final list representing all word classes contained 27,819 person-descriptive terms.

\section{PSYCHOLEXICAL CLASSIFICATION PROCEDURE}

The person-descriptive terms selected from the dictionary were classified by 13 judges preparing their MA theses and doctoral dissertations in psycholexical research, whose mother tongue was Polish. For the purpose of the study, we adapted the taxonomy procedure from a German lexical study (Angleitner et al., 1990), which is one of the most often used procedures in this kind of research and which offers the widest possibilities of subsequently applying the results of classification both in the inclusive/non-restrictive approach and in the narrow/restrictive approach. First, the judges decided whether or not a given word was comprehensible to them. Next, based on his or her own understanding of the word as well as on the dictionary definition, each judge decided whether or not a given word qualified as a person-descriptive term. In the third step, the judges rated the valence of the word on a 5-point scale (1 - strongly negative, 2 - negative, 3 - neutral, 4 - positive, 5 - strongly positive). After the judges' ratings were averaged, the words for which the mean rating ranged from 1.00 to 2.74 were classified as negative, those with mean ratings between 2.75 and 3.25 as neutral, and those with mean ratings between 3.26 and 5.00 as positive. 
Every word classified as a person-descriptive term was further classified into one of 16 subcategories, which in turn made up seven higher-order categories: (1) dispositions; (1a) temperament and character; (1b) mental abilities and talents or their absence; (2) temporary conditions; (2a) emotions, internal states, and readiness to react; (2b) bodily states; (2c) activities and behaviors; (3) social aspects; (3a) roles and relationships; (3b) hobbies and interests; (3c) social effects: reactions of others; (3d) pure evaluations; (3e) attitudes and worldviews; (4) overt characteristics and appearance; (4a) anatomy, constitution, and morphology; (4b) external attributes: appearance and posture; (5) specialist and technical terms referring to (5a) mental/psychological or (5b) physical chronic diseases or disorders; (6) physical abilities and talents or their absence; (7) metaphorical terms. The last category was non-classifiable terms.

The original classification proposal by Angleitner et al. (1990) was modified in order to streamline the process of judges making classification decisions as well as based on the experience acquired when performing the taxonomy of the lexicon of individual differences in Belarusian (Gorbaniuk et al., 2014), Ukrainian (Gorbaniuk et al., 2018), and Russian (Ivanova et al., 2017) and in the course of earlier research on the Polish lexicon (Gorbaniuk et al., 2011; Gorbaniuk, Budzińska, Owczarek, Bożek, \& Juros, 2013). The "specialist, rare, and technical terms" category was too general and vaguely defined, which made the judges' decisions arbitrary and marked by low interjudge agreement in this category. For this reason, we narrowed it down to a more precisely defined category: "specialist and technical terms referring to (5a) mental/psychological or (5b) physical chronic diseases or disorders," and at the same time distinguished "metaphorical terms" as a separate category. We distinguished "physical abilities and talents or their absence" as an additional category, modeled on the taxonomy of the Filipino language (Church, Katigbak, \& Reyes, 1996) and absent from the original classification system: abilities that influence strength, flexibility, endurance, balance and coordination. Also, for the same reasons, we introduced the "hobbies and interests" subcategory, thus reducing the number of unclassified person-descriptive terms which described this kind of individual differences, and at the same time making the classification process faster.

Due to the ambiguity of some of the words, the judges were allowed to classify a person-descriptive term into more than one lexical category/subcategory. A term was eventually assigned to a particular category if it was classified into it by at least seven of the thirteen judges. The rating process took 16 to 18 weeks. The judges were supposed to send a classified $1 / 16$ of the list of person-descriptive terms at the end of each week - a requirement that was meant to motivate them to work systematically.

\section{CATEGORIZATION VALIDITY AND RELIABILITY}

Before the judges commenced their classification work, they twice went through group-based lexical training and performed a trial classification of two lists of words, containing 115 and 200 terms, respectively. After every trial classification the judges received individual feedback concerning the correctness of the classification; typical errors were discussed in a group, and errors specific to particular judges were discussed with them on an individual basis.

To assess the validity of the classification, we selected 240 adjectives that had been classified into subcategories in the course of the earlier lexical taxonomy of the Polish language (Gorbaniuk et al., 2011) by at least eight out of nine judges, recognizing them as prototypal of their respective subcategories and treating them as the external criterion when assessing the validity of judges' decisions in the current study of the Polish language lexicon. After thorough training, each of the 13 judges independently decided whether or not the adjectives met the criteria for person-descriptive terms and classified them into 16 categories/subcategories. Next, we computed the proportion of decisions consistent with the external criterion in the total number of prototypal adjectives from a given category/subcategory (the first column in Table 2). As the second validity index, we computed Cohen's $\kappa$ coefficient of agreement between the judge's decision and the external criterion based on all the 240 adjectives (the second column in Table 2), taking into account the false alarms that decrease the validity level. The average validity of classifications into categories ranged from $69.2 \%$ to $95.7 \%$ (Cohen's $\kappa$ : from .63 to .92) for higher-order categories and from $73.1 \%$ to $95.9 \%$ (Cohen's $\kappa$ : from .74 to .98) for subcategories. These validity figures can be regarded as satisfactory (Fleiss, 1981).

The last two columns of Table 2 contain information concerning inter-rater composite reliability based on the classifications of the list of 27,813 terms by 13 judges. Alpha coefficients ranged from .82 to .97 for higher-order categories and from .64 to .98 for subcategories. In general, the inter-rater reliability coefficients should be regarded as satisfactory. Compared to the levels of composite reliability (cf. Angleitner et al., 1990; Di Blas \& Forzi, 1998; Mlačić \& Ostendorf, 2005; Szarota, Ashton, \& Lee, 2007) and validity (cf. Angleitner et al., 1990) in other similar taxonomies, they also turn out to be very good.

\section{RESULTS}

The results of the analyses of the contents of the universal dictionary of the Polish language (Dubisz, 2008) allowed research question Q1 to be answered: 
O. Gorbaniuk, A. Korczak, N. Toruj, A. Czarnejko, K. Macheta, M. Jałoszewska, M. Charęzińska-Nowocień, R. Karpiński, Ł. Garwoliński, T. Misiuro, M. Zygnerska, I. Bojan, K. Rykowska, P. Wawrzaszek, J. Jeliński, M. Hawryluk

Table 2

Validity and reliability of judges' decisions

\begin{tabular}{|c|c|c|c|}
\hline \multirow[t]{2}{*}{ Category/subcategory } & \multicolumn{2}{|c|}{ Criterion validity } & \multirow{2}{*}{$\begin{array}{c}\text { Inter-judge } \\
\text { agreement } \\
\alpha\end{array}$} \\
\hline & $\mathrm{P}$ & $\kappa$ & \\
\hline Person-descriptive term & 80.0 & .79 & - \\
\hline 1. Dispositions & 93.6 & .83 & .90 \\
\hline 1a. temperament and character & 89.2 & .74 & .91 \\
\hline 1b. mental/psychological abilities, talents, or their absence & 82.6 & .81 & .86 \\
\hline 2. Temporary conditions & 95.7 & .91 & .82 \\
\hline 2a. experiential states & 95.4 & .85 & .77 \\
\hline 2b. physical and bodily states & 92.3 & .89 & .88 \\
\hline 2c. observable activities & 88.7 & .92 & .64 \\
\hline 3. Social and reputational aspects & 94.5 & .92 & .89 \\
\hline 3a. roles and relationships & 88.2 & .93 & .94 \\
\hline 3b. hobbies and interests & 92.3 & .96 & .92 \\
\hline 3c. social effects: reactions of others & 88.7 & .92 & .82 \\
\hline 3d. pure evaluations & 83.1 & .75 & .86 \\
\hline 3e. attitudes and worldviews & 96.4 & .98 & .98 \\
\hline 4. Overt characteristics and appearance & 95.6 & .89 & .95 \\
\hline 4a. anatomy, constitution, and morphology & 85.1 & .86 & .94 \\
\hline 4b. appearance and looks & 95.9 & .86 & .89 \\
\hline 5. Diseases and disorders & 81.5 & .90 & .97 \\
\hline 5a. mental/psychological & 73.1 & .89 & .95 \\
\hline 5b. physical & 81.5 & .84 & .96 \\
\hline 6. Physical abilities, talents, or their absence & 83.8 & .85 & .84 \\
\hline 7. Metaphorical terms & 69.2 & .63 & .87 \\
\hline
\end{tabular}

Note. $\mathrm{P}$ - mean percentage of decisions consistent with the external criterion; $\mathrm{\kappa}$ - average Cohen's kappa coefficient of agreement with the external criterion, $\alpha$-inter-rater composite reliability coefficient based on the classifications of 27,813 person-descriptive terms.

the percentage of words in the dictionary describing differences between people is $27.8 \%$ (see Table 3 ). Verbs form the largest group of person-descriptive terms, accounting for $40.3 \%$. The second largest group consists of nouns $(34.2 \%)$, including attribute-nouns (19.0\%) and type-nouns (15.2\%). They are followed by adjectives, whose proportion among person-descriptive terms is $19.5 \%$. The smallest group is that of adverbs (6.0\%). Because the authors of the dictionary did not include participles other than those classified as adjectival participles and used as person-descriptive adjectives (e.g., zrównoważony [even-tempered], otwarty [frank]), we did not distinguish participles as a category distinct from adjectives (cf. Saloni, 2012).

In the study, we adopted a narrow operational definition of personality traits by narrowing its range to descriptors of traits that are psychological in nature and relatively stable over time, i.e. (1a) to descriptors of temperament and character, for which almost everyone would agree are attributes of personality (cf. Saucier, 1997), and (1b) to descriptors of mental abilities and talents or their absence. Answering research question Q2, it was established that in the total lexicon of person-descriptive terms, $20.1 \%$ are words describing personality traits (see Table 3 ). The largest proportion of dispositional descriptors among different word classes in the analyzed Polish language dictionary is found in the case of adverbs (36.5\%, e.g., powściagliwie [guardedly], rozważnie [prudently], samokrytycznie [self-critically], impulsywnie [impulsively]), type-nouns (33.9\%, e.g., gadula [chatterbox], pracuś [eager beaver, workaholic], perfekcjonista 
Table 3

The psycholexical classification of Polish person-descriptive terms

\begin{tabular}{|c|c|c|c|c|c|c|c|c|c|c|c|c|}
\hline \multirow[t]{2}{*}{ Category/subcategory } & \multicolumn{2}{|c|}{$\begin{array}{l}\text { All word } \\
\text { classes }\end{array}$} & \multicolumn{2}{|c|}{$\begin{array}{l}\text { Adjectives } \\
\text { \& parti- } \\
\text { ciples }\end{array}$} & \multicolumn{2}{|c|}{ Adverbs } & \multicolumn{2}{|c|}{$\begin{array}{l}\text { Attribute- } \\
\text { nouns }\end{array}$} & \multicolumn{2}{|c|}{$\begin{array}{l}\text { Type- } \\
\text { nouns }\end{array}$} & \multicolumn{2}{|c|}{ Verbs } \\
\hline & $f$ & $\%$ & $f$ & $\%$ & $f$ & $\%$ & $f$ & $\%$ & $f$ & $\%$ & $f$ & $\%$ \\
\hline 1. Dispositions & 5598 & 20.1 & 1641 & 30.0 & 612 & 36.5 & 1442 & 33.9 & 1029 & 19.3 & 916 & 8.1 \\
\hline $\begin{array}{l}\text { 1a. temperament and } \\
\text { character }\end{array}$ & 4083 & 14.7 & 1362 & 24.9 & 519 & 30.9 & 1090 & 25.6 & 839 & 15.7 & 302 & 2.7 \\
\hline $\begin{array}{l}\text { 1b. mental/psychological } \\
\text { abilities, talents, or } \\
\text { their absence }\end{array}$ & 1020 & 3.7 & 225 & 4.1 & 60 & 3.6 & 287 & 6.8 & 154 & 2.9 & 305 & 2.7 \\
\hline 2. Temporary conditions & 7502 & 27.0 & 677 & 12.4 & 127 & 7.6 & 609 & 14.3 & 68 & 1.3 & 6050 & 53.6 \\
\hline 2a. experiential states & 2360 & 8.5 & 404 & 7.4 & 115 & 6.9 & 466 & 11.0 & 22 & 0.4 & 1367 & 12.1 \\
\hline $\begin{array}{l}\text { 2b. physical and bodily } \\
\text { states }\end{array}$ & 807 & 2.9 & 226 & 4.1 & 9 & 0.5 & 129 & 3.0 & 37 & 0.7 & 418 & 3.7 \\
\hline 2c. observable activities & 3959 & 14.2 & 53 & 1.0 & 6 & 0.4 & 41 & 1.0 & 11 & 0.2 & 3855 & 34.1 \\
\hline $\begin{array}{l}\text { 3. Social and } \\
\text { reputational aspects }\end{array}$ & 13311 & 47.9 & 3267 & 59.7 & 1136 & 67.7 & 1884 & 44.3 & 4505 & 84.4 & 2664 & 23.6 \\
\hline 3a. roles and relationships & 3843 & 13.8 & 520 & 9.5 & 46 & 2.7 & 230 & 5.4 & 2650 & 49.6 & 469 & 4.2 \\
\hline 3b. hobbies and interests & 327 & 1.2 & 26 & 0.5 & 1 & 0.1 & 42 & 1.0 & 219 & 4.1 & 39 & 0.3 \\
\hline $\begin{array}{l}\text { 3c. social effects: } \\
\text { reactions of others }\end{array}$ & 1084 & 3.9 & 233 & 4.3 & 147 & 8.8 & 63 & 1.5 & 19 & 0.4 & 626 & 5.5 \\
\hline $3 \mathrm{~d}$. pure evaluations & 5232 & 18.8 & 1919 & 35.1 & 861 & 51.3 & 917 & 21.6 & 1083 & 20.3 & 515 & 4.6 \\
\hline $\begin{array}{l}\text { 3e. attitudes and } \\
\text { worldviews }\end{array}$ & 1633 & 5.9 & 446 & 8.2 & 60 & 3.6 & 475 & 11.2 & 530 & 9.9 & 129 & 1.1 \\
\hline $\begin{array}{l}\text { 4. Overt characteristics } \\
\text { and appearance }\end{array}$ & 1250 & 4.5 & 610 & 11.2 & 12 & 0.7 & 103 & 2.4 & 303 & 5.7 & 238 & 2.1 \\
\hline $\begin{array}{l}\text { 4a. anatomy, constitution, } \\
\text { and morphology }\end{array}$ & 635 & 2.3 & 363 & 6.6 & 6 & 0.4 & 58 & 1.4 & 186 & 3.5 & 33 & 0.3 \\
\hline 4b. appearance and looks & 502 & 1.8 & 215 & 3.9 & 3 & 0.2 & 20 & 0.5 & 90 & 1.7 & 179 & 1.6 \\
\hline $\begin{array}{l}\text { 5. Diseases and } \\
\text { disorders }\end{array}$ & 966 & 3.5 & 135 & 2.5 & 15 & 0.9 & 599 & 14.1 & 224 & 4.2 & 10 & 0.1 \\
\hline 5a. mental/psychological & 360 & 1.3 & 60 & 1.1 & 12 & 0.7 & 171 & 4.0 & 114 & 2.1 & 8 & 0.1 \\
\hline 5b. physical & 601 & 2.2 & 71 & 1.3 & 2 & 0.1 & 437 & 10.3 & 103 & 1.9 & 1 & 0.0 \\
\hline $\begin{array}{l}\text { 6. Physical abilities, } \\
\text { talents, or their } \\
\text { absence }\end{array}$ & 250 & 0.9 & 62 & 1.1 & 17 & 1.0 & 54 & 1.3 & 76 & 1.4 & 42 & 0.4 \\
\hline 7. Metaphorical terms & 1215 & 4.4 & 223 & 4.1 & 31 & 1.8 & 132 & 3.1 & 260 & 4.9 & 573 & 5.1 \\
\hline $\begin{array}{l}\text { Terms without majority } \\
\text { classifications }\end{array}$ & 2169 & 7.8 & 80 & 1.5 & 45 & 2.7 & 103 & 2.4 & 6 & 0.1 & 1936 & 17.1 \\
\hline Terms in the initial pool & 27813 & 100.0 & 5469 & 100.0 & 1678 & 100.0 & 4250 & 100.0 & 5338 & 100.0 & 11294 & 100.0 \\
\hline
\end{tabular}


O. Gorbaniuk, A. Korczak, N. Toruj, A. Czarnejko, K. Macheta, M. Jałoszewska, M. Charęzińska-Nowocień, R. Karpiński, Ł. Garwoliński, T. Misiuro, M. Zygnerska, I. Bojan, K. Rykowska, P. Wawrzaszek, J. Jeliński, M. Hawryluk

[perfectionist]), and adjectives (30.0\%, e.g., leniwy [lazy], energiczny [energetic], kreatywny [creative]). In the case of verbs, this proportion is the lowest (8.1\%, e.g., lękać się [to fear], izolować się [to seclude oneself], chytrzyć [to scheme]).

In answer to research question Q3 we compared the psycholexical structure of different word classes. One will observe that a characteristic feature of verbs is a very high proportion of words describing states (53.6\%), particularly behavioral states (34.1\%), due to the considerable proportion of action verbs (e.g., $d z w o n i c ́$ [to call], jąkać się [to stutter], lecieć [to fly]), which should be considered an element of the specificity of this part of speech. The situation is quite the contrary in this respect in the case of attributenouns, among which we identified only $1.3 \%$ of state descriptors (e.g., pokrzykiwanie [shouting], drżenie [trembling]).

The predominant group among attribute-nouns comprises descriptors of individuals' social functioning $(84.4 \%)$; words describing social roles and relations are particularly numerous $(49.6 \%$; e.g., braterstwo [brotherhood], podrzędność [subordination], niepetnoletność [minority]). The proportion of attribute-nouns in the total number of person-descriptive terms classified into this subcategory is $69.9 \%$.

In the pure evaluation subcategory, adjectives and adverbs account for the largest proportion. Every third adjective (35.1\%, e.g., brzydki [ugly], cenny [precious], dziadowski [shabby]) and every second adverb (51.3\%, e.g., fenomenalnie [phenomenally], fajnie [great], wadliwie [defectively]) was classified into the pure evaluation subcategory.

In worldview description, nouns are much more important (accounting for $61.5 \%$ of worldview descriptors): $11.2 \%$ of type-nouns (e.g., rusofob [Russophobe], scjentysta [scientist], lewicowiec [leftwinger]) and $9.9 \%$ of attribute-nouns (e.g., faszyzm [fascism], stoicyzm [stoicism], liberalizm [liberalism]) were classified into this subcategory.

Among the words found in the dictionary and classified as external appearance descriptors, ad- jectives make up the largest group (48.8\%) - even though descriptors of external attributes constitute only $11.2 \%$ of all adjectives (e.g., chudy [thin], wysoki [tall], umięśniony [muscular]).

Among the words in the dictionary describing mental and physical disorders, type-nouns account for the largest proportion (62.0\%, e.g., dyslektyk [dyslexic], schizofrenik [schizophrenic], lunatyk [somnambulist]).

The frequency of words whose metaphorical meanings refer to human characteristics is similar for various word classes and ranges from $1.8 \%$ (for adverbs, e.g., paraliżująco [paralyzingly], goraczkowo [feverishly], szatańsko [devilishly]) to $5.1 \%$ (for verbs, e.g., puszyć się [to put on airs], wykoleić się [to become demoralized], skamienieć [to petrify]).

Terms describing individual differences can be analyzed not only in terms of content but also in terms of valence (see Table 4). The results of analyses show that the proportion of negative descriptors (47.2\%) is the highest in the lexicon of person-descriptive terms, while positive characteristics are in a minority (only 17.9\%). These proportions strongly differ across the types of word classes. A characteristic feature of verbs and attribute nouns is the much higher proportion of neutral descriptors $(43.1 \%$ and $42.7 \%$, respectively) than in the case of the remaining word classes. Negative descriptors are predominant in the case of type-nouns (56.6\%) and adjectives (51.2\%).

In the psycholexical studies conducted to date, dispositional descriptors (restrictive/narrow approach) enjoyed the greatest interest. Table 5 presents a comparison of different types of word classes describing personality traits in terms of their valence. The proportion of neutral terms among personality descriptors is approximately two times lower in each type of word classes than their proportion among all person-descriptors. The proportion of neutral dispositional descriptors is the highest in the case of verbs $(27.6 \%)$. Negative descriptors are predominant in the remaining types of word classes, accounting for more than half of all terms in their

Table 4

Valence of person-descriptive terms

\begin{tabular}{|c|c|c|c|c|c|c|c|c|c|c|c|c|}
\hline \multirow[t]{3}{*}{ Valence } & \multirow{2}{*}{\multicolumn{2}{|c|}{$\begin{array}{l}\text { All word } \\
\text { classes }\end{array}$}} & \multicolumn{10}{|c|}{ Word class } \\
\hline & & & \multicolumn{2}{|c|}{$\begin{array}{c}\text { Adjectives } \\
\text { \& participles }\end{array}$} & \multicolumn{2}{|c|}{ Adverbs } & \multicolumn{2}{|c|}{$\begin{array}{c}\text { Attribute- } \\
\text { nouns }\end{array}$} & \multicolumn{2}{|c|}{ Type-nouns } & \multicolumn{2}{|c|}{ Verbs } \\
\hline & $f$ & $\%$ & $f$ & $\%$ & $f$ & $\%$ & $f$ & $\%$ & $f$ & $\%$ & $f$ & $\%$ \\
\hline Negative & 13170 & 47.4 & 2798 & 51.2 & 817 & 48.7 & 2407 & 56.6 & 2389 & 44.8 & 4889 & 43.3 \\
\hline Neutral & 9652 & 34.7 & 1372 & 25.1 & 321 & 19.1 & 850 & 20.0 & 2278 & 42.7 & 4863 & 43.1 \\
\hline Positive & 4991 & 17.9 & 1299 & 23.8 & 540 & 32.2 & 993 & 23.4 & 671 & 12.6 & 1542 & 13.7 \\
\hline Total & 27813 & 100.0 & 5469 & 100.0 & 1678 & 100.0 & 4250 & 100.0 & 5338 & 100.0 & 11294 & 100.0 \\
\hline
\end{tabular}


Table 5

Valence of personality-descriptive terms

\begin{tabular}{|c|c|c|c|c|c|c|c|c|c|c|c|c|}
\hline \multirow[t]{3}{*}{ Valence } & \multirow{2}{*}{\multicolumn{2}{|c|}{$\begin{array}{l}\text { All word } \\
\text { classes }\end{array}$}} & \multicolumn{10}{|c|}{ Word class } \\
\hline & & & \multicolumn{2}{|c|}{$\begin{array}{l}\text { Adjectives } \\
\& \text { participles }\end{array}$} & \multicolumn{2}{|c|}{ Adverbs } & \multicolumn{2}{|c|}{$\begin{array}{l}\text { Attribute- } \\
\text { nouns }\end{array}$} & \multicolumn{2}{|c|}{ Type-nouns } & \multicolumn{2}{|c|}{ Verbs } \\
\hline & $f$ & $\%$ & $f$ & $\%$ & $f$ & $\%$ & $f$ & $\%$ & $f$ & $\%$ & $f$ & $\%$ \\
\hline Negative & 3016 & 53.9 & 903 & 55.0 & 322 & 52.6 & 754 & 52.3 & 695 & 67.5 & 371 & 40.5 \\
\hline Neutral & 864 & 15.4 & 216 & 13.2 & 67 & 10.9 & 169 & 11.7 & 156 & 15.2 & 253 & 27.6 \\
\hline Positive & 1718 & 30.7 & 522 & 31.8 & 223 & 36.4 & 519 & 36.0 & 178 & 17.3 & 292 & 31.9 \\
\hline Total & 5598 & 100.0 & 1641 & 100.0 & 612 & 100.0 & 1442 & 100.0 & 1029 & 100.0 & 916 & 100.0 \\
\hline
\end{tabular}

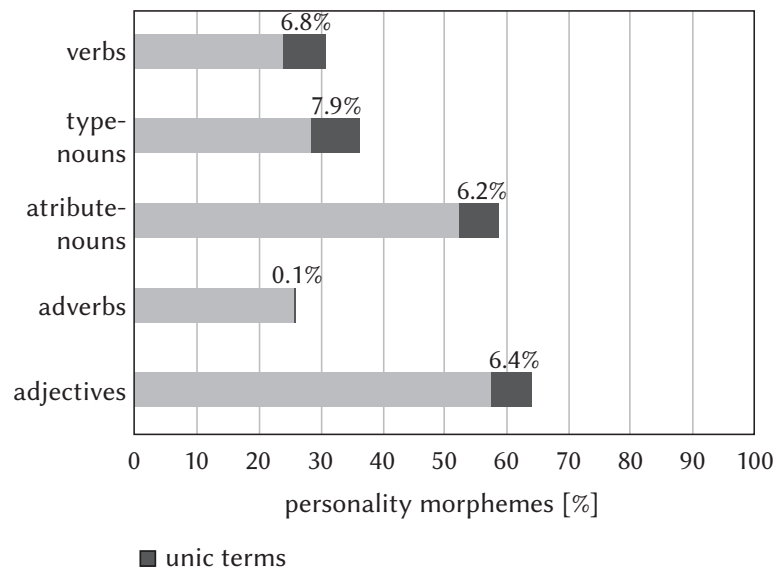

Figure 1. Frequency of use of word classes in personality description and their unique contribution.

categories, and their percentage is the highest in the case of attribute-nouns (67.5\%).

The list of descriptors of individual differences contained words representing different word classes, some of which referred to the same meaning and had a common morpheme (e.g., pracowity [diligent], pracowitość [diligence], pracuś [eager beaver, workaholic], pracowicie [diligently]); this resulted in redundancy in the personality lexicon. Particularly in the case of dispositional descriptors we analyzed 5,598 words for identical morphemes and similar meanings, identifying 1,979 irredundant morphemes with unique dispositional meaning; we treated antonyms having the same morpheme as referring to the same characteristic but to the opposite end of the continuum (e.g., przyjazny [friendly], nieprzyjazny [unfriendly]). Figure 1 illustrates the results of the analyses. In answer to research question Q4 we established that adjectives describe the highest percentage of the nonredundant personality lexicon (64.0\% of morphemes), $6.4 \%$ of adjectives being irreplaceable by other word classes (e.g., defensywny [defensive], koncyliacyjny [conciliatory], łatwy [easy], merytoryczny [knowledgeable, to-the-point]). To express the meaning of the remaining $36.0 \%$ of morphemes, it is necessary to use other categories of words: verbs, type-nouns, or attribute-nouns. On the other hand, limiting research of the personality lexicon only to adjectives would mean ignoring these morphemes. As in the case of adjectives, each of these word categories makes its unique contribution to the representation of the Polish personality lexicon that cannot be replaced by any other category of words. This contribution is $6.2 \%$ in the case of attribute-nouns (e.g., chciejstwo [wishful thinking], kuraż [courage], rezerwa [reserve], werwa [verve]), 7.9\% in the case of type-nouns (e.g., kataryn$k a$ [chatterbox], bałaguła [roisterer], cykor [chicken], dusigrosz [skinflint], jęczydusza [grumbler], niedoraj$d a$ [loser]), and $6.8 \%$ in the case of verbs (e.g., kotować [to wangle], kraść [to steal], załatwiać [to fix]).

In answer to research question Q3 we can state that the vast majority of markers distinguished by De Raad et al. (2014) are represented in the Polish personality lexicon. A total of $92 \%$ of the 241 crosslanguage Big Six markers identified in cross-language analyses were listed among Polish person-descriptive terms. For three dimensions - Agreeableness, Intellect, and Honesty-Humility - we found 95\% correspondence of the list of markers with the Polish personality lexicon. For the Conscientiousness dimension the correspondence level was 93\%, and for the remaining two dimensions (Extraversion and Emotional Stability) it was $88 \%$. Some of the differences between the Polish personality lexicon and the broadest list of markers of the cross-language Big Six stems from the fact that in order to reproduce the meaning of some English words it would be necessary in Polish to use longer expressions (e.g., goal-oriented - zorientowany na cel), and these were not included in the list, in accordance with the methodology we adopted. The next issue is the fact that some markers, translated into Polish, are words describing mainly emotional states or visible activities (e.g., szczęśliwy [happy], smutny [sad], uśmiechnięty [smiling]) and were not rated as dispositional by the majority of judges. 
O. Gorbaniuk, A. Korczak, N. Toruj, A. Czarnejko, K. Macheta, M. Jałoszewska, M. Charęzińska-Nowocień, R. Karpiński, Ł. Garwoliński, T. Misiuro, M. Zygnerska, I. Bojan, K. Rykowska, P. Wawrzaszek, J. Jeliński, M. Hawryluk

\section{DISCUSSION}

The presented research results are the third attempt at conducting qualitative and quantitative analyses of the Polish lexicon of person-descriptive terms. As opposed to the previous studies, limited only to the adjective lexicon (Szarota, 1995; Szarota et al., 2007; Gorbaniuk et al., 2011), the current analyses systematize the complete lexicon used to describe human characteristics, including adjectives, adjectival participles, adverbs, attribute-nouns, type-nouns, and verbs. The source of the lexicon that we used was the most recent and up-to-date universal dictionary of Polish, which is in the top quarter in terms of size among the studies conducted so far (median: 70,000 entries). From the psychometric point of view, the distinctive feature of the present study is the verification of judges' decisions not only in terms of reliability but also in terms of validity, which is rare in psycholexical research (cf. Angleitner et al., 1990; Gorbaniuk et al., 2014; Gorbaniuk et al., 2018; Ivanova et al., 2017).

The percentage of words describing differences between people in the Polish lexicon represented by the dictionary we used is relatively high (27.8\%) compared, for instance, to the studies devoted to the German (Angleitner et al., 1990), Italian (Di Blas \& Forzi, 1999), Croatian (Mlačić \& Ostendorf, 2005) and Czech (Hřebíčková, 2007) lexicons, similar in terms of vocabulary size, the investigated word classes and the procedure, where the proportion of person-descriptive terms was lower than $20 \%$. Also the proportion of personality descriptors is very high compared to the taxonomy of other languages based on a similar procedure: it accounts for $5.6 \%$ of the entire lexicon included in the dictionary and for $20.1 \%$ of persondescriptive terms, whereas in other languages these percentages usually are much lower (cf. Angleitner et al., 1990; Hřebíčková, 2007; Mlačić \& Ostendorf, 2005). One of the causes is the research procedure enabling an exhaustive analysis of the meanings of terms, since the judges took into account both colloquial and dictionary meanings. On the one hand, this made it possible to avoid the limitations stemming from the structure of the dictionary, failing to fully reflect the colloquial meanings of words; on the other hand, taking dictionary meanings into account made it possible to avoid the linguistic limitations of each individual judge. The richness of the Polish personality lexicon is also confirmed by the fact that it contains $92 \%$ of the 241 markers of the Big Six factors used in cross-language comparisons by De Raad et al. (2014), which makes it possible at least to replicate the Big Six and, potentially, to supplement it with other factors if they are not represented to a sufficient degree by adjectives.

The results of the classification of person-descriptive terms representing different word classes con- firm De Raad and Ostendorf's (1996) assertion about the frequency of personality adjectives being higher than that of type-nouns. What is more, we found a predominance of adjectives over all the remaining word classes in personality description. This, however, does not mean that adjectives exhaust the Polish personality lexicon. The comparative analysis of words representing different linguistic categories but having the same morpheme and meaning revealed that in more than $36 \%$ of cases the Polish personality lexicon requires the use of word classes other than adjectives. Therefore, limiting the research on the structure of personality description to adjectives involves the risk of reductionism, as pointed out by Saucier (2003) as well as De Raad and Barelds (2008). It is necessary to study the lexicon of various linguistic categories (attribute-nouns, type-nouns, and verbs) in order to confirm the adequacy of the six dimensions identified in research narrowed to the adjective lexicon (Szarota et al., 2007; Gorbaniuk et al., 2013) for the description of the entire Polish personality lexicon. What is particularly needed is research based on a non-redundant and exhaustive list of personality descriptors representing various parts of speech, which would fully follow the idea of the lexical assumption (Goldberg, 1981).

To date, verbs belong to the most often neglected word classes in psycholexical studies, although many researchers at the same time emphasize their uniqueness in comparison with other descriptors of individual differences (De Raad \& Barelds, 2008; Quevedo-Aguado, Iraegui, Anivarro, \& Ross, 1996). So far, attempts to learn the structure of the lexicon of personality-verbs have been made only in Dutch (De Raad, Mulder, Kloosterman, \& Hofstee, 1988) and Czech (Hřebíčková, Ostendorf, Osecká, \& Cermák, 1999). The Polish lexicon of person-descriptive verbs can be a good starting point for future research in both restrictive and non-restrictive approaches, including cross-language comparisons (e.g. Polish, Dutch and Czech).

The identified Polish lexicon of person-descriptive terms is not limited to the lexicon of dispositions terms referring to relatively stable characteristics which is usually examined in the narrow/restrictive approach, dominant in psycholexical research. Therefore, the complete lexicon of individual differences can be a point of departure for inclusive/unrestrictive studies on the Polish lexicon, analogous to those devoted to the Dutch language (De Raad \& Barelds, 2008). Moreover, thanks to the use of the German taxonomy (Angleitner et al., 1990), we identified lexicons for 13 subcategories of individual differences unrelated to personality, which can be objects of separate lexical studies and may contribute to the achievement of taxonomic agreement on the classification of differences between people, for instance, in terms of worldview (cf. Krauss, 2006; Saucier, 2000), cognitive, 
emotional, and motivational reactions to other people (cf. Mlačić, 2016; Saucier, 2010), social effects (cf. De Raad et al., 2005), as well as emotional, motivational, or cognitive states. Due to the small number of languages investigated so far in non-dispositional terms, it is still too early for cross-cultural generalizations.

Although the authors' intention was to perform an exhaustive classification of the Polish lexicon of person-descriptive terms, the ideal achievement of this aim will encounter two kinds of barriers, which are present in all psycholexical studies (De Raad, 1996, 1998; Saucier, Hampson, \& Goldberg, 2000). The first barrier is the dictionary representing the Polish lexicon: even though we chose the most complete and up-to-date Polish dictionary, considered by linguists to be one of the least normative dictionaries, for reasons of space it does not contain all the parts of speech and all the related specific meanings that may be significant from the point of view of psychology. In particular, what should be checked is the completeness of the lexicon of active and passive participles, which can be formed based on the selected verbs. Because in Polish they are used similarly to adjectives to describe differences between people, participles may be a valuable supplement to the adjective lexicon of personality descriptors. Second, the necessity of receiving the majority of judges' votes in the process of classification results in part of the lexicon of individual differences not being unambiguously classified into specific categories and subcategories, which means these terms cannot be further used in quantitative studies. Third, De Raad and Barelds (2008) point out the role of idioms.

The analyses performed as part of the present study stopped at classifying terms into the categories and subcategories borrowed from the German psycholexical study. The next stage should be quantitative research aimed at identifying the factor structure of the lexicon of individual differences, following either the non-restrictive approach or an approach restricted to a particular category or subcategory of person-descriptive terms (e.g. social affects, worldviews or temporary states). This in turn makes it necessary to refine the list of descriptors for the purposes of specific studies, taking into account their possible redundancy, usage frequency, familiarity to an average respondent, unambiguity, etc. Conducting quantitative research will make it possible to conclude the entire series of studies on the Polish lexicon of individual differences.

\section{CONCLUSIONS}

Qualitative studies on the lexicon of individual differences are crucial to the outcome of psycholexical studies. Like any other study in psychology, they should be subject to multifaceted psychometric validation, including assessment of the validity and reliability of judges' decisions. If language is to be a source of knowledge about individual differences and a chance to reach taxonomic agreement in academic debate, it is necessary to conduct comprehensive studies into the lexicon of individual differences of many languages, not limited to one part of speech, whose outcome will make it possible to analyze various categories of these differences without limiting them to narrowly defined personality traits.

\section{ACKNOWLEDGMENTS}

This paper was partly supported by the National Science Centre grant (Poland) [registration number 2017/25/N/HS6/02618] to Tomasz Misiuro.

\section{REFERENCES}

Almagor, M., Tellegen, A., \& Waller, N. (1995). The Big Seven model: A cross-cultural replication and further exploration of the basic dimensions of natural language of trait descriptions. Journal of Personality and Social Psychology, 69, 300-307.

Angleitner, A., Ostendorf, F., \& John, O. P. (1990). Towards a taxonomy of personality descriptors in German. A psycho-lexical study. European Journal of Personality, 4, 89-118.

Ashton, M. C., \& Lee, K. (2005). A defence of the lexical approach to the study of personality structure. European Journal of Personality, 19, 5-24.

Ashton, M. C., Lee, K., Perugini, M., Szarota, P., de Vries, R. E., Di Blas, L., \& De Raad, B. (2004). A sixfactor structure of personality-descriptive adjectives: Solutions from psycholexical studies in seven languages. Journal of Personality and Social Psychology, 86, 356-366.

Benet-Martínez, V., \& Waller, N. G. (1997). Further evidence for the cross-cultural generality of the Big Seven Factor model: Indigenous and imported Spanish personality constructs. Journal of Personality, 65, 567-598.

Church, A. T., Katigbak, M. S., \& Reyes, J. A. S. (1996). Toward a taxonomy of trait adjectives in Filipino: Comparing personality lexicons across cultures. European Journal of Personality, 10, 3-24.

Costa, P. T. Jr., McCrae, R. R., \& Dye, D. A. (1991). Facet scales for agreeableness and conscientiousness: A revision of the NEO Personality Inventory. Personality and Individual Differences, 12, 887-898.

De Raad, B. (1998). Five Big, Big Five issues: Rationale, content, structure, status, and cross-cultural assessment. European Psychologist, 3, 113-124.

De Raad, B., \& Barelds, D. P. H. (2008). A new taxonomy of Dutch personality traits based on a comprehensive and unrestricted list of descriptors. 
O. Gorbaniuk, A. Korczak, N. Toruj, A. Czarnejko, K. Macheta, M. Jałoszewska, M. Charęzińska-Nowocień, R. Karpiński, Ł. Garwoliński, T. Misiuro, M. Zygnerska, I. Bojan, K. Rykowska, P. Wawrzaszek, J. Jeliński, M. Hawryluk

Journal of Personality and Social Psychology, 94, 347-364.

De Raad, B., Barelds, D. P., Levert, E., Ostendorf, F., Mlačić, B., Blas, L. D., Hřebíčková, M., Szirmák, Z., Szarota, P., Perugini, M., \& Church, A. T. (2010). Only three factors of personality description are fully replicable across languages: A comparison of 14 trait taxonomies. Journal of Personality and Social Psychology, 98, 160-173.

De Raad, B., Barelds, D. P. H., Timmerman, M. E., De Roover, K., Mlačić, B., \& Church, A. T. (2014). Towards a pancultural personality structure: Input from 11 psycho-lexical studies. European Journal of Personality, 28, 497-510.

De Raad, B., Mulder, E., Kloosterman, K., \& Hofstee, W. K. (1988). Personality-descriptive verbs. European Journal of Personality, 2, 81-96.

De Raad, B., \& Ostendorf, F. (1996). Quantity and quality of trait-descriptive type nouns. European Journal of Personality, 10, 45-56.

De Raad, B., Perugini, M., Hřebíčková, M., \& Szarota, P. (1998). Lingua Franca of personality: Taxonomies and structures based on the psycholexical approach. Journal of Cross-Cultural Psychology, 29, 212-232.

De Raad, B., Van Oudenhoven, J. P., \& Hofstede, M. (2005). Personality terms of abuse in three cultures: Type nouns between description and insult. European Journal of Personality, 19, 153-165.

Di Blas, L., \& Forzi, M. (1998). An alternative taxonomic study of personality-descriptive adjectives in the Italian language. European Journal of Personality, 12, 75-101.

Di Blas, L., \& Forzi, M. (1999). Refining a descriptive structure of personality attributes in the Italian language: The abridged Big Three circumplex structure. Journal of Personality and Social Psychology, 76, 451-481.

Dubisz, S. (Ed.) (2008). Uniwersalny stownik języka polskiego [The Universal Dictionary of the Polish Language]. Warszawa: Wydawnictwo Naukowe PWN.

Fleiss, J. L. (1981). Statistical methods for rates and proportions. New York: John Wiley.

Galton, F. (1884). Measurement of character. Fortnightly Review, 36, 179-185.

Goldberg, L. R. (1981). Language and individual differences. The search for universals in personality lexicons. In L. Wheeler (Ed.), Review of personality and social psychology (Vol. 2, pp. 141-165). Beverly Hills, CA: Sage.

Goldberg, L. R. (1990). An alternative "description of personality”. The Big Five factor structure. Journal of Personality and Social Psychology, 59, 1216-1229.

Gorbaniuk, O., Czarnecka, E., \& Chmurzyńska, M. (2011). Taxonomy of person-descriptive terms in Polish: A psycho-lexical study. Current Problems of Psychiatry, 12, 100-106.
Gorbaniuk, O., Budzińska, A., Owczarek, M., Bożek, E., \& Juros, K. (2013). The factor structure of Polish personality-descriptive adjectives: An alternative psycho-lexical study. European Journal of Personality, 27, 304-318.

Gorbaniuk, O., Kulewicz, P., Gorbaniuk, J., Kordon, A., Leoszko, W., Ivanova, A., \& Suchomska, M. (2014). Taksonomia psycholeksykalna języka białoruskiego [A psycho-lexical taxonomy of Belarusian language]. Current Problems of Psychiatry, 15, 89-95.

Gorbaniuk, O., Mirowich, A., Leoszko, W., Gorbaniuk, J., Kordon, A., Świderska, M., Kuts, O., \& Korczak, A. (2018). A psycholexical classification of Ukrainian descriptors of individual differences. Current Problems of Psychiatry, 19, 1-8.

Hřebíčková, M. (2007). The lexical approach to personality description in the Czech context. Ceskoslovenská Psychologie, 51, 50-61.

Hřebíčková, M., Ostendorf, F., Osecká, L., \& Cermák, I. (1999). Taxonomy and structure of Czech personality-relevant verbs. Personality Psychology in Europe, 7, 51-65

Ivanova, A., Gorbaniuk, O., Kordon., A., Gorbaniuk, J., Leoszko, W., \& Kulewicz, P. (2017). The language lexicon as the source of knowledge of individual differences: a psycholexical study of Russian. Paper presented on XVIII International Slavonic Conference Literatures, cultures and East Slavonic languages with regard to their historical time. Zielona Góra, Poland, 22-23.05.2017.

John, O. P., \& Srivastava, S. (1999). The Big Five trait taxonomy: History, measurement, and theoretical perspectives. In O. P. John, R. W. Robins, \& L. A. Pervin (Eds.), Handbook of personality: Theory and research (pp. 114-158). New York, NY: Guilford Press.

Krauss, S. (2006). Does ideology transcend culture? A preliminary examination in Romania. Journal of Personality, 74, 1219-1256.

Lee, K., \& Ashton, M. C. (2004). Psychometric properties of the HEXACO Personality Inventory. Multivariate Behavioral Research, 39, 329-358.

Lee, K., \& Ashton, M. C. (2006). Further assessment of the HEXACO Personality Inventory: Two new facet scales and an observer report form. Psychological Assessment, 18, 182-191.

McCrae, R. R., \& Costa, P. X. (1985). Updating Norman's "adequate taxonomy": Intelligence and personality dimensions in natural language and in questionnaires. Journal of Personality and Social Psychology, 49, 710-721.

McCrae, R. R., \& Costa, P. X. (1987). Validation of the Five-Factor Model of personality across instruments and observers. Journal of Personality and Social Psychology, 52, 81-90.

Mlačić, B., \& Ostendorf, F. (2005). Taxonomy and structure of Croatian personality-descriptive adjectives. European Journal of Personality, 19, 117-152. 
Mlačić, B. (2016). Social and reputational aspects of personality. International Journal of Personality Psychology, 2, 15-36.

Peabody, D., \& De Raad, B. (2002). The substantive nature of psycholexical personality factors: A comparison across languages. Journal of Personality and Social Psychology, 83, 983-997.

Quevedo-Aguado, M. P., Iraegui, A., Anivarro, E. M., \& Ross, P. (1996). Linguistic descriptors of personality in the Spanish language: A first taxonomic study. European Journal of Personality, 10, 25-34.

Saloni, Z. (2012). Podstawy teoretyczne „Stownika gramatycznego języka polskiego" [Theoretical basics of "Polish Grammar Dictionary"]. Warszawa: Sowa.

Saucier, G. (1997). Effects of variable selection on the factor structure of person descriptors. Journal of Personality and Social Psychology, 73, 1296-1312.

Saucier, G. (2000). Isms and the structure of social attitudes. Journal of Personality and Social Psychology, 78, 366-385.

Saucier, G. (2003). Factor structure of English-language personality type nouns. Journal of Personality and Social Psychology, 85, 695-708.

Saucier, G. (2009a). Semantic and linguistic aspects of personality. In P. Corr \& G. Matthews (Eds.), The Cambridge handbook of personality psychology (pp. 379-399). New York: Cambridge University Press.

Saucier, G. (2009b). Recurrent personality dimensions in inclusive lexical studies: Indications for a Big Six structure. Journal of Personality, 77, 1577-1614.

Saucier, G. (2010). The structure of social effects: Personality as impact on others. European Journal of Personality, 24, 222-240.

Saucier, G., Hampson, S. E., \& Goldberg, L. R. (2000). Cross-language studies of lexical personality factors. In S. E. Hampson (Ed.), Advances in personality psychology (Vol. 1, pp. 1-36). London: Routledge.

Saucier, G., \& Srivastava, S. (2015). What makes a good structural model of personality? Evaluating the Big Five and alternatives. In M. Mikulincer \& P. R. Shaver (Eds.), APA Handbook of Personality and Social Psychology, Vol. 4: Personality Processes and Individual Differences (pp. 283-305). New York: Cambridge University Press.

Simons, G. F., \& Fennig, C. D. (2018). Ethnologue: Languages of the World. Dallas, Texas: SIL International.

Szarota, P. (1995). Polska Lista Przymiotnikowa (PLP): Narzędzie do diagnozy pięciu wielkich czynników osobowości [Polish Adjective List: Instrument to assess the five-factor model of personality]. Studia Psychologiczne, 33, 227-256.

Szarota, P., Ashton, M., \& Lee, K. (2007). Taxonomy and structure of the Polish personality lexicon. European Journal of Personality, 21, 823-852.
Tellegen, A., \& Waller, N. G. (1987). Reexamining basic dimensions of natural language trait descriptors. Paper presented at the 95th annual meeting of the American Psychological Association, New York. 